\title{
A stromatolitic cyanobacterial crust in a Mediterranean stream optimizes organic matter use
}

\author{
Anna M. Romaní, Sergi Sabater* \\ Departament d'Ecologia, Facultat de Biologia, Universitat de Barcelona, Avgda Diagonal 645, E-08028 Barcelona, Spain
}

\begin{abstract}
The bedrock of La Solana (NE Spain) stream is a thick calcareous cyanobacterial crust with a layered structure similar to a stromatolite. Different algal patches, which appear along with seasonal changes (especially discharge, temperature and light), characterize the stromatolite. This structure has a great capacity for organic matter utilization, as indicated by the high extracellular enzymatic activities ( $\beta$-glucosidase, $\beta$-xylosidase and phosphatase) measured in the stromatolitic algal patches over an annual cycle. However, each patch showed a particular ability in the use of organic matter since a different hydrolytic potential capacity was measured. The highest $\beta$-glucosidase and $\beta$-xylosidase activities were measured in the mixed community (cyanobacterial crust with a sparsely developed overstorey), indicating that the understorey of this stromatolitic crust is highly active. In the ZygnemaSpirogyra community, autotrophic activity might enhance $\beta$-glucosidase activity in spring, whilst in the diatom bloom (which appeared in May-June), polysaccharides released by algae and mucilagenous material from the diatom stalks might regulate the ectoenzymatic activities. The adaptation of the Rivularia community to oligotrophic conditions occurring in summer, autumn and winter is shown by the extremely high phosphatase activity, related to the low phosphorus concentration in stream water. The appearance and progressive substitution of the different patches can be interpreted as the adaptive response to the most available organic matter source, as well as a way of surviving the drastic environmental changes characteristic of Mediterranean streams
\end{abstract}

KEY WORDS: Organic matter - Stromatolite - Ectoenzymatic activities . Bacteria ' Algae . Mediterranean streams

\section{INTRODUCTION}

Microbial mats are dense benthic communities of microorganisms which can give rise to laminated rocks known as stromatolites (Stal 1995). Stromatolites are formed through lithification processes such as binding and trapping of sediment particles, precipitated minerals (e.g. calcite) and accumulation of incompletely mineralized organic matter (Chafetz \& Buczynski 1992). Bacteria, and especially cyanobacteria, play a significant role in producing stromatolites (Abdelahad \& Bazzichelli 1989, Chafetz \& Buczynski 1992). Extracellular polysaccharides released by diatoms are also involved (Winsborough \& Golubic 1987). Algae and

\footnotetext{
- Addressee for correspondence.

E-mail: ssabater@porthos.bio.ub.es
}

cyanobacteria living in microbial mats are distributed heterogeneously and change their pigment composition in response to the incident light, temperature, and water current (Stal et al. 1985, Hawes 1993, Pinckney et al. 1995bj. Cyanobacteria-dominated microbial mat communities are restricted to oligotrophic environments. At high nutrient levels diatoms may be competitive dominants (Pinckney et al. 1995a).

Microorganisms living in stromatolitic microbial mats have high metabolic activities (Cohen \& Rosenberg 1989). The photoautotrophic and the heterotrophic communities of microbial mats are closely linked, showing high rates of photosynthesis and organic matter utilization (Canfield \& Des Marais 1993, Paerl et al. 1993), although a higher production to respiration ratio was observed in a stromatolitic mat (Pinckney et al. 1995b). 
Our aim was to investigate organic matter utilization in a stromatolitic cyanobacterial crust which developed in a Mediterranean stream. La Solana bedrock shows distinct patches characterized by different dominating groups of taxa which follow a seasonal succession (Guasch \& Sabater 1994). Each algal patch has a characteristic photosynthetic behaviour (Guasch \& Sabater 1995). We hypothesize that organic matter degradation processes may also be particular to each algal patch and that their temporal dynamics in the stream are related to different abilities in organic matter use. The capacity to break down organic matter was studied by analyzing potential ectoenzymatic activities. Extracellular enzymatic hydrolysis of macromolecules is the first step in microbial degradation of macromolecular organic compounds in aquatic environments (Marxsen \& Witzel 1990, Chróst 1991). Microbial ectoenzymes (those bound to the cell surface) act outside the cell, converting high-molecularweight molecules to low-molecular-weight molecules which are readily utilizable by heterotrophic microbes (Chróst 1990). We analyzed the ectoenzymatic activities of $\beta$-glucosidase, $\beta$-xylosidase and phosphatase of each patch monthly during an annual study. These enzymes are involved in the degradation of polysaccharides (cellulose, hemicellulose) and orthophosphoric monoesters which are plant and/or animal polymers originating in rivers from both autochthonous and allochthonous sources. Electron transport was also measured and used as a general estimate of the respiratory activity of each stromatolitic patch.

\section{MATERIALS AND METHODS}

Study site. La Solana, located in NE Spain, is an undisturbed second-order stream draining a calcare- ous basin (Martí et al. 1994). The calcareous bedrock of La Solana is covered by a lithified layer of cyanobacteria and diatoms, creating a crusted structure similar to a stromatolitic microbial mat. The distribution of different algal patches on the cyanobacterial crust changes during the year, due to variations in discharge and light (Guasch \& Sabater 1994). High photosynthetic and respiration rates were observed in La Solana (Guasch \& Sabater 1994, 1995), which may require high rates of heterotrophic carbon utilization.

This Mediterranean stream is subject to drastic seasonality, and large fluctuations in discharge (minimum $01 \mathrm{~s}^{-1}$ in summer, maximum $99.9 \mathrm{l} \mathrm{s}^{-1}$ in autumn) and temperature (minimum $0.2^{\circ} \mathrm{C}$ in winter, maximum $24.1^{\circ} \mathrm{C}$ in summer) have been observed (Martî et al. 1994, Martí \& Sabater 1996). The riparian vegetation is not well developed, with only a sparse canopy. Light is not limiting, being maximum in summer (maximum value of $910 \mu \mathrm{E} \mathrm{m}^{-2} \mathrm{~s}^{-1}$ ). The nutrient content is very low, especially for soluble reactive phosphorus (5 to $10 \mu \mathrm{g} \mathrm{l}^{-1}$ ) (Table 1)

Sampling. Samples of the stromatolitic crust were collected monthly from January 1994 to February 1995. The calcareous cyanobacterial crust is permanent over the year and the different algae developing over the crust characterize the visually different algal patches: the Rivularia community, the Zygnema-Spirogyra community, the diatom bloom and the mixed community (Guasch \& Sabater 1995). Each patch, consisting of an understorey (the permanent crust) and an overstorey, was defined when appearing in the stream over more than $10 \%$ of the streambed surface. The algal cover on the stream surface was evaluated by several transects along a $100 \mathrm{~m}$ reach. Relative density of algal cover was established from 0 to $100 \%$ in the area defined by an underwater viewer $\left(0.16 \mathrm{~m}^{2}\right)$, which was used to visualize the relative densities along each transect.

Table 1. Physical and chemical characteristics of La Solana stream during the study period. Values are seasonal means, except summer values which correspond to early July, when water was only in small pools. From then until the end of August the stream was totally dry. Values in brackets are the standard deviations of the mean ( $\mathrm{n}=6$ but $n=3$ in summer and autumn 1994)

\begin{tabular}{|c|c|c|c|c|c|}
\hline & $\begin{array}{c}\text { Winter } \\
1994\end{array}$ & $\begin{array}{c}\text { Spring } \\
1994\end{array}$ & $\begin{array}{c}\text { Summer } \\
1994\end{array}$ & $\begin{array}{l}\text { Autumn } \\
1994\end{array}$ & $\begin{array}{c}\text { Winter } \\
1995\end{array}$ \\
\hline Discharge $\left(1 \mathrm{~s}^{-1}\right)$ & $10(2.1)$ & $12(3.3)$ & $0(0)$ & $26(12)$ & $18(3.2)$ \\
\hline Temperature $\left({ }^{\circ} \mathrm{C}\right)$ & $0.7(0.3)$ & $11.6(3.9)$ & $24.8(4.6)$ & $8.6(4.2)$ & $2.9(2.8)$ \\
\hline Light $\left(\mu E \mathrm{~m}^{-2} \mathrm{~s}^{-1}\right)$ & $140(35)$ & $496(301)$ & $710(387)$ & $188(122)$ & $112(27)$ \\
\hline Conductivity $\left(\mu \mathrm{S} \mathrm{cm}^{-1}\right)$ & $470(16)$ & $400(23)$ & $606(53)$ & $405(48)$ & $408(1.8)$ \\
\hline $\mathrm{pH}$ & $8.3(0.1)$ & $8.2(0.1)$ & $7.7(0.2)$ & $8.0(0.3)$ & $8.5(0.6)$ \\
\hline Oxygen ( $\mathrm{mg} \mathrm{l}^{-1}$ ) & $10.9(3.6)$ & $8.0(3.3)$ & $1.5(0.8)$ & $11.0(3.7)$ & $11.8(0.1)$ \\
\hline $\mathrm{NO}_{3}-\mathrm{N}\left(\mu \mathrm{g} \mathrm{I} \mathrm{I}^{-1}\right)$ & $181(51)$ & $71(65)$ & $269(63)$ & $187(83)$ & $202(116)$ \\
\hline $\mathrm{NH}_{4}-\mathrm{N}\left(\mu \mathrm{g} \mathrm{I}^{-1}\right)$ & $35(1.3)$ & $24(13)$ & $2939(1040)$ & $27(17)$ & $29(15)$ \\
\hline $\operatorname{SRP}\left(\mu \mathrm{g}^{-1}\right)$ & $1.6(0.5)$ & $2.1(2.6)$ & $65(51)$ & $4.7(0.9)$ & $1.3(1.1)$ \\
\hline DIN:SRP & $465(214)$ & $764(1130)$ & $49(20)$ & $102(49)$ & $116(83)$ \\
\hline $\mathrm{DOC}\left(\mathrm{mg} \mathrm{l}^{-1}\right)$ & $1.8(0.3)$ & $6.9(5.5)$ & $128(9.6)$ & $5.7(2.9)$ & $4.7(1.0)$ \\
\hline $\operatorname{DIC}\left(\mathrm{mg} \mathrm{l}^{-1}\right)$ & $62.8(5.1)$ & $59.6(4.1)$ & $40.1(4.8)$ & $47.4(5.4)$ & $48.0(3.1)$ \\
\hline
\end{tabular}


On each sampling date, pieces of each patch 10.5 to $1 \mathrm{~cm}$ thick) were placed in sterile glass vials with stream water. Samples were kept cold (on ice) and in the dark for transport. Samples from July and August 1994 (dry period) were transported wrapped in aluminium foil. The analyzed samples were approximately $1.1 \mathrm{~cm}^{2}$ in surface area. Samples for chlorophyll analysis were frozen and kept in the dark until pigment extraction. For bacterial cell counts, samples were placed in sterile glass vials with $2 \%$ formalin. Activity measurements (extracellular enzyme analyses, photosynthetic activity and respiratory activity) were measured on the same day, 2 to $3 \mathrm{~h}$ after sampling.

On each sampling date, temperature, $\mathrm{pH}$, dissolved oxygen and conductivity were measured in the field. Incident light was measured with a LiCor quantum sensor (Li-192SB). Water velocity was measured in the field by recording the increase in conductivity with time after a slug injection of a concentrated chloride solution to the stream water, approximately $50 \mathrm{~m}$ upstream from the sampling point (Gordon et al. 1993). Discharge was calculated by mass balance from integration of the concentration hydrograph (Triska et al. 1989).

Filtered (precombusted Whatman GF/F filters) water samples (3 replicates for each analysis) were taken in order to analyze inorganic nutrients (nitrate, ammonium and soluble reactive phosphorus), as well as dissolved organic carbon (DOC) and dissolved inorganic carbon (DIC). Nitrate was analyzed by ion chromatography (Kontron) with an IC-Pack anion column $(4.5 \times$ $50 \mathrm{~mm}$ ) and an ultraviolet detector. Ammonium and soluble reactive phosphorus were analyzed spectrophotometrically following the procedure of Grasshoff et al. (1983). The DIN:SRP ratio was calculated as the molar ratio of dissolved inorganic nitrogen (DIN, ammonium plus nitrate) to soluble reactive phosphorus. DIC and DOC were measured with a total organic carbon analyzer (Shimadzu, TOC-5000). In summer 1994 the stream dried out; July water samples were collected from some pools and no water was collected in August.

Activity measurements. The ectoenzymatic potential activities of $\beta$-D-glucosidase (EC 3.2.1.21), $\beta$-D-xylosidase (EC 3.2.1.37) and phosphatase (EC 3.1.3.1-2) were determined spectrofluorometrically using MUF (methylumbelliferyl)-substrate analogues (4-MUF $\beta$ D-glucoside, 4-MUF $\beta$-D-xyloside, and 4-MUF phosphate from Sigma-Aldrich). Samples (5 replicates) and formaldehyde-killed controls (2 replicates) for each patch were incubated with $2 \mathrm{ml}$ of each substrate ( $0.3 \mathrm{mmol}^{-1}$, saturation conditions) in the dark with continuous shaking for $1 \mathrm{~h}$ at ambient stream temperature (Sabater \& Romaní 1996). Two blanks of filter-ster- ilized stream water were also incubated. After addition of $0.05 \mathrm{M}$ glycine buffer, pH 10.4, fluorescence was measured at $455 \mathrm{~nm}$ under $365 \mathrm{~nm}$ excitation (Kontron, SFM25).

Primary production was measured as $\mathrm{H}^{14} \mathrm{CO}_{3}$ incorporation. Samples (3 replicates) and formaldehydekilled controls were incubated at $150 \mu \mathrm{E} \mathrm{m} \mathrm{m}^{-2} \mathrm{~s}^{-1}$. Dark replicates were included. Incubation was perfomed in a shaker for $2 \mathrm{~h}$ at ambient stream temperature, injecting $1 \mu \mathrm{Ci}$ of $\mathrm{NaH}^{14} \mathrm{CO}_{3}$ into each tube (Sabater \& Romaní 1996). Radioactivity was measured in a Packard Tri-carb 1500 liquid scintillation analyser. Primary production was only analyzed in the mixed community.

Respiratory activity (Electron Transport System, ETS) was assayed by measuring the reduction of the electron transport acceptor INT (2-(p-iodophenyl)-3( $p$-nitrophenyl)-5-phenyl tetrazolium chloride) into INT-formazan (iodonitrotetrazolium formazan) (Blenkinsopp \& Lock 1990). Five replicates and 2 killed controls for each patch were incubated in $0.02 \% \mathrm{w} / \mathrm{v}$ INT solution in a shaker at ambient stream temperature for 10 to $12 \mathrm{~h}$ in the dark (Sabater \& Romaní 1996).

Algal biomass and bacterial density. Chlorophyll a was measured ( 3 replicates) after extraction in $90 \%$ acetone for $12 \mathrm{~h}$ in the dark at $4^{\circ} \mathrm{C}$. To ensure total chlorophyll extraction, samples were sonicated for $4 \mathrm{~min}$ at the end of the extraction period. Chlorophyll concentration was determined spectrophotometrically after filtration (GF/F Whatman) of the extract, following Jeffrey \& Humphrey (1975). The ratio of chlorophyll to carotenoids and/or chlorophyll degradation products was measured as the quotient of the optical densities at 430/665 nm (Margalef 1983). Algal composition and community structure were determined for all patches. Bacterial density was estimated in triplicate after sonication ( $90 \mathrm{~s}$ plus $90 \mathrm{~s}$ ). After appropriate dilution, fixed samples were stained for 5 min with DAPI ( $\left.2 \mu \mathrm{g} \mathrm{ml}^{-1}\right)$, filtered through $0.2 \mu \mathrm{m}$ irgalan black stained polycarbonate filters and counted using a fluorescence microscope. The different bacterial morphotypes were also observed.

Organic carbon, nitrogen, and organic matter biofilm content. The stromatolite was completely dried $\left(2 \mathrm{~d}\right.$ in the oven at $110^{\circ} \mathrm{C}$ ) and then ground. Each sample was treated with hydrochloric acid $(2 \mathrm{~N})$ to eliminate inorganic carbon, placed under vacuum for total drying, and analyzed for carbon and nitrogen with a $\mathrm{C} / \mathrm{N}$ Analyzer 1500 Carlo Erba using vanadium pentoxide as the oxidation catalyzer.

On the first sampling date (January 1994), the organic matter content of the Rivularia community, the Zygnema-Spirogyra community, and the mixed community was measured as ash-free dry weight (AFDW), after $4 \mathrm{~h}$ at $450^{\circ} \mathrm{C}$, and was expressed as $\mathrm{mg} \mathrm{cm}^{-2}$. 
Data analysis. The Rivularia community, ZygnemaSpirogyra community and the diatom bloom were compared with the mixed community on each sampling date using a 2-tailed $t$-test. One-way analysis of variance was performed for each variable in the different patches. Differences between patches were analyzed by Tukey's multiple comparison test. Correlation analyses (Pearson coefficient) were performed with biological and environmental variables.

\section{RESULTS}

\section{Physical and chemical characteristics}

Minimum temperature and light levels occurred in winter (Table 1). Maximum oxygen, nitrate and ammonium levels in the flowing stream water were measured in winter and autumn. Soluble reactive phosphorus (SRP) concentration was in general very low, with the minimum values measured in winter. The maximum DOC was found in spring and autumn. During the drought period (July and August 1994), some water remaining in small pools contained a high nutrient concentration and low $\mathrm{pH}$ and oxygen. Although some rain occurred during August $(30 \mathrm{~mm})$, water in the stream did not flow again until September.

\section{Description of patch community}

The patches of the stromatolitic cyanobacterial crust, embedded in calcareous material, consist of an understorey (the permanent crust) and an overstorey (algae and cyanobacteria covering the permanent crust). The understorey showed distinct layers. The upper layer (1 to $3 \mathrm{~mm}$ thick), green in colour, was composed mainly of Rivularia biasolettiana Menegh. and some filamentous cyanobacteria (Schizothrix penicillata [Kütz] Gom., S. affinis Lemm. and Homeothrix sp.). The green algae Mougeotia sp., Spirogyra sp. and Zygnema sp. and the diatom Cymbella sp. were also present in this layer. The second layer ( 2 to $6 \mathrm{~mm}$ thick), green-yellowish in colour, was exclusively made up of $R$. biasolettiana (with more empty sheaths and less heterocysts) and filaments of $S$. penicillata. The bacterial community within this structure was mainly composed $(80 \%)$ of cocci and coccobacilli (0.2 to $0.4 \mu \mathrm{m}$ diameter), but chains of rod-shaped bacteria embedded in a mucilagenous material and filaments were also observed. Some fungal hyphae were interspersed in the structure. The organic carbon content of this structure ranged between 3.2 and $17.2 \%$, while the organic nitrogen was 0.24 to $1.08 \%$.
The differences in the 4 patches were attributable to differences in the overstorey. In the mixed community, small spots of $R$. biasolettiana and Zygnema sp. or Mougeotia sp. were found over the permanent crust. The mixed community covered 40 to $80 \%$ of the streambed area over all the study period but only 10 to $15 \%$ during the diatom bloom in spring 1994 . Chlorophyll $a$ in this community fluctuated during the study period, ranging between 8.4 to $22.4 \mathrm{\mu g} \mathrm{cm}^{-2}$ (Fig. 1a) and the high OD430/OD665 ratio revealed a remarkable proportion of carotenoids (Fig. 2). Bacterial density showed 2 phases, being between 6.6 and $8.3 \times$ $10^{9}$ cells $\mathrm{cm}^{-2}$ in winter and spring 1994 and decreasing after the drought to $1.8-3.9 \times 10^{9}$ bacteria $\mathrm{cm}^{-2}$ (Fig. 1b). Organic matter content was $53.12 \pm 18.64 \mathrm{mg}$ AFDW $\mathrm{cm}^{-2}$, significantly higher than in both the Rivu-

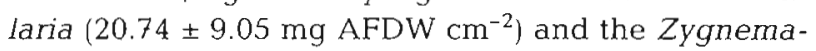
Spirogyra $\left(34.9 \pm 8.9 \mathrm{mg}\right.$ AFDW $\left.\mathrm{cm}^{-2}\right)$ communities (ANOVA, $\mathrm{p}<0.0001$ ).

The colonies of Rivularia biasolettiana had a different appearance in winter 1994 (clear green colonies) than in summer and autumn (dark green colonies). In May 1994 there were no colonies of $R$. biasolettiana due to the development of the diatom bloom. In winter 1995 the Rivularia community did not appear. Chlorophyll a densities in this community were similar to the mixed community, except for July 1994 when it was significantly lower (Fig. 1a). Bacterial density ranged between 6.2 and $17.3 \times 10^{9}$ cells $\mathrm{cm}^{-2}$, being significantly higher than the mixed community in January and July 1994 (Fig. 1b). The Rivularia community had the highest bacterial density and the highest OD430/OD665 ratio of all the patches (Fig. 2).

The Zygnema-Spirogyra community developed in spring 1994 and winter 1995 and its overstorey was dominated by Zygnema, Spirogyra and Mougeotia taxa, some diatoms being part of its periphyton (Cyclotella cf. kutzingiana, Cymbella cf. helvetica, Achnanthes minutissima Kütz. Epithemia sp.). This community became desiccated during the dry period (summer 1994) and sloughed off in autumn when discharge increased. The community appeared again in winter 1995. Chlorophyll $a$ and bacterial density were not significantly different from those in the mixed community on any sampling date (Fig. 1a, b). In terms of annual averages, chlorophyll was higher than in the Rivularia and mixed communities (Fig. 2).

The diatom bloom appeared in spring 1994. It was a white-grey mucilagenous material, which covered nearly $80 \%$ of the cyanobacterial crust. It was mainly composed of the stalked diatoms Cymbella affinis Kütz. and C. helvetica Kütz., but also of Cyclotella cf. kutzingiana, Fragilaria capucina Desmazières, Synedra ulna (Nietzsche) Ehr. and Achnanthes minutissima. The diatom bloom disappeared in July when, due to 


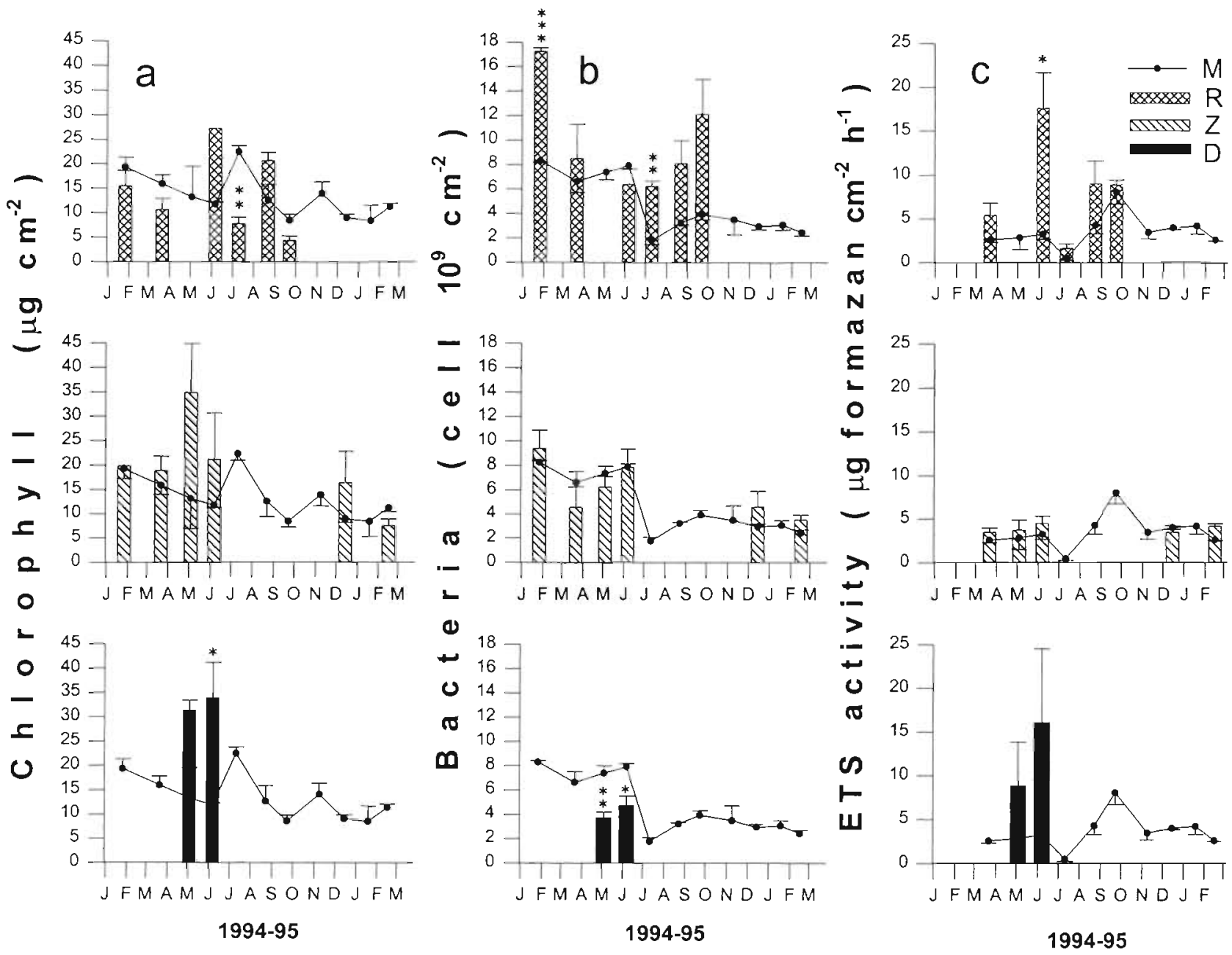

Fig. 1. Temporal variation of (a) chlorophyll a density, (b) bacterial cell density, and (c) respiratory (electron transport system, ETS) activity in the different algal patches. M: mixed community; R: Rivularia community; Z: Zygnema-Spirogyra community; D: diatom bloom. Error bars represent standard errors of the mean, $n=3$ in (a) and (b), $n=5$ in (c). Significant differences between the $R, Z$ or D community and the $M$ community on a given sampling date are indicated: ${ }^{*} p<0.05, \cdots p<0.01, \cdots p<0.001(t$-test)

the drought, the mucilaginous material became totally dry. Chlorophyll a content was ca $32 \mu \mathrm{g} \mathrm{cm}^{-2}$ (Fig. 1a), significantly higher than in the mixed community (Fig. 1a). However, bacterial density (ca $4.2 \times 10^{9}$ bacteria $\mathrm{cm}^{-2}$ ) was significantly lower than in the mixed community (Fig. 1b). Organic carbon and nitrogen in the diatom bloom were significantly higher than in the other patches, but the molar ratio between organic carbon and organic nitrogen was not (Fig. 2).

\section{Primary production and respiration}

Photosynthetic activity, only measured in the mixed community, had an annual average of $8.18 \mu \mathrm{g} \mathrm{C} \mathrm{cm}^{-2}$ $\mathrm{h}^{-1}$. It was maximum in spring 1994 and increased again in winter 1995 (Table 2). Primary productivity increased up to 374 -fold between winter and spring
1994. However, values in winter 1995 were similar to those in spring-summer 1994.

ETS activity in the mixed community was lowest in July 1994 and increased in September 1994 (Fig. 1C). The Rivularia community showed a high peak in ETS activity in June, while values in the Zygnema-Spirogyra community were not significantly different from those in the mixed community (Fig. 1c). When compar-

Table 2. Photosynthetic activity $\left(\mu \mathrm{g} \mathrm{C} \mathrm{cm}^{-2} \mathrm{~h}^{-1}\right)$ in the mixed community of La Solana stream during the study period. Values are seasonal means and standard deviations

\begin{tabular}{|lccccc|}
\hline & $\begin{array}{c}\text { Winter } \\
1994\end{array}$ & $\begin{array}{c}\text { Spring } \\
1994\end{array}$ & $\begin{array}{c}\text { Summer } \\
1994\end{array}$ & $\begin{array}{c}\text { Autumn } \\
1994\end{array}$ & $\begin{array}{c}\text { Winter } \\
1995\end{array}$ \\
\hline Mean & 0.034 & 12.72 & 9.76 & 1.90 & 11.21 \\
SD & 0.013 & 15.30 & 11.20 & 1.78 & 5.44 \\
\hline
\end{tabular}


ing annual averages, ETS activity was significantly higher in the Rivularia community and in the diatom bloom than in the mixed and Zygnema-Spirogyra communities (Fig. 2).

\section{Extracellular enzymatic activities}

$\beta$-Glucosidase activity in the mixed community reached maximum values during the drought, and minimum values were measured in winter (1994 and 1995) and spring 1994 (Fig. 3a). In the Rivularia community, $\beta$-glucosidase was significantly lower than in the mixed community in January, March and June 1994, but no significant differences were found in the summer months (Fig. 3a). Values in the Zygnema-Spirogyra community were also lower in January and March 1994 but significantly higher in May (Fig. 3a). BGlucosidase activity in the diatom bloom increased from May to June, but values were significantly lower than in the mixed community (Fig. 3a). Concerning annual averages, $\beta$-glucosidase activity was the highest in the mixed community and the lowest in the diatom bloom (Fig. 2).

$\beta$-Xylosidase activity in the mixed community was lowest during spring and early summer and increased during the drought, maintaining the high values until winter 1995 (Fig. 3b). The Rivularia community and the Zygnema-Spirogyra community showed a significantly lower $\beta$-xylosidase activity than the mixed community
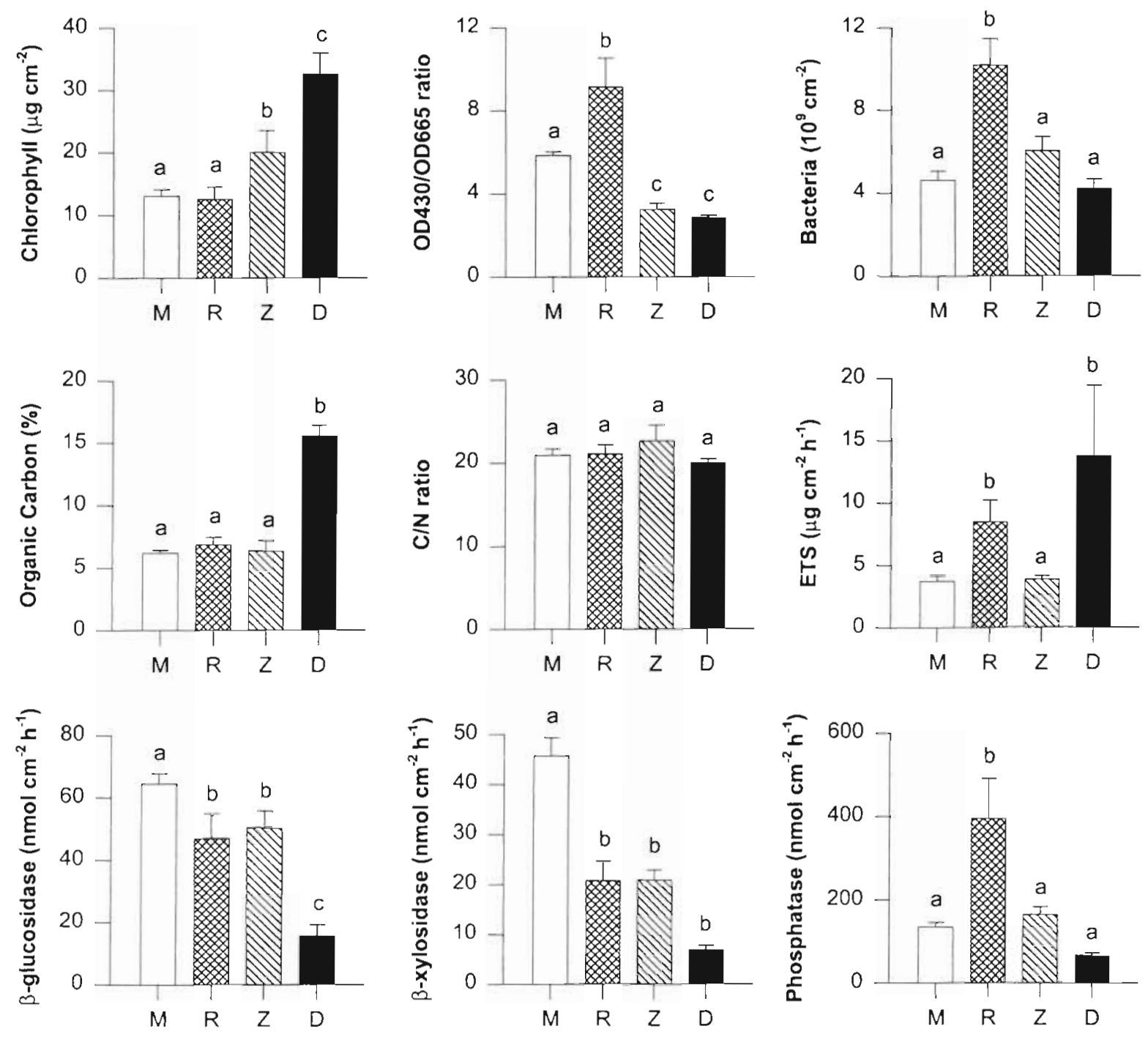

Fig. 2. Annual averages and standard errors of the mean (error bars) in the different algal patches. M: mixed community; R: Rivularia community; Z: Zygnema-Spirogyra community; $D$ : diatom bloom. Letters a, b, c show significantly different groups found by Tukey's multiple comparison test $(p<0.05)$ 


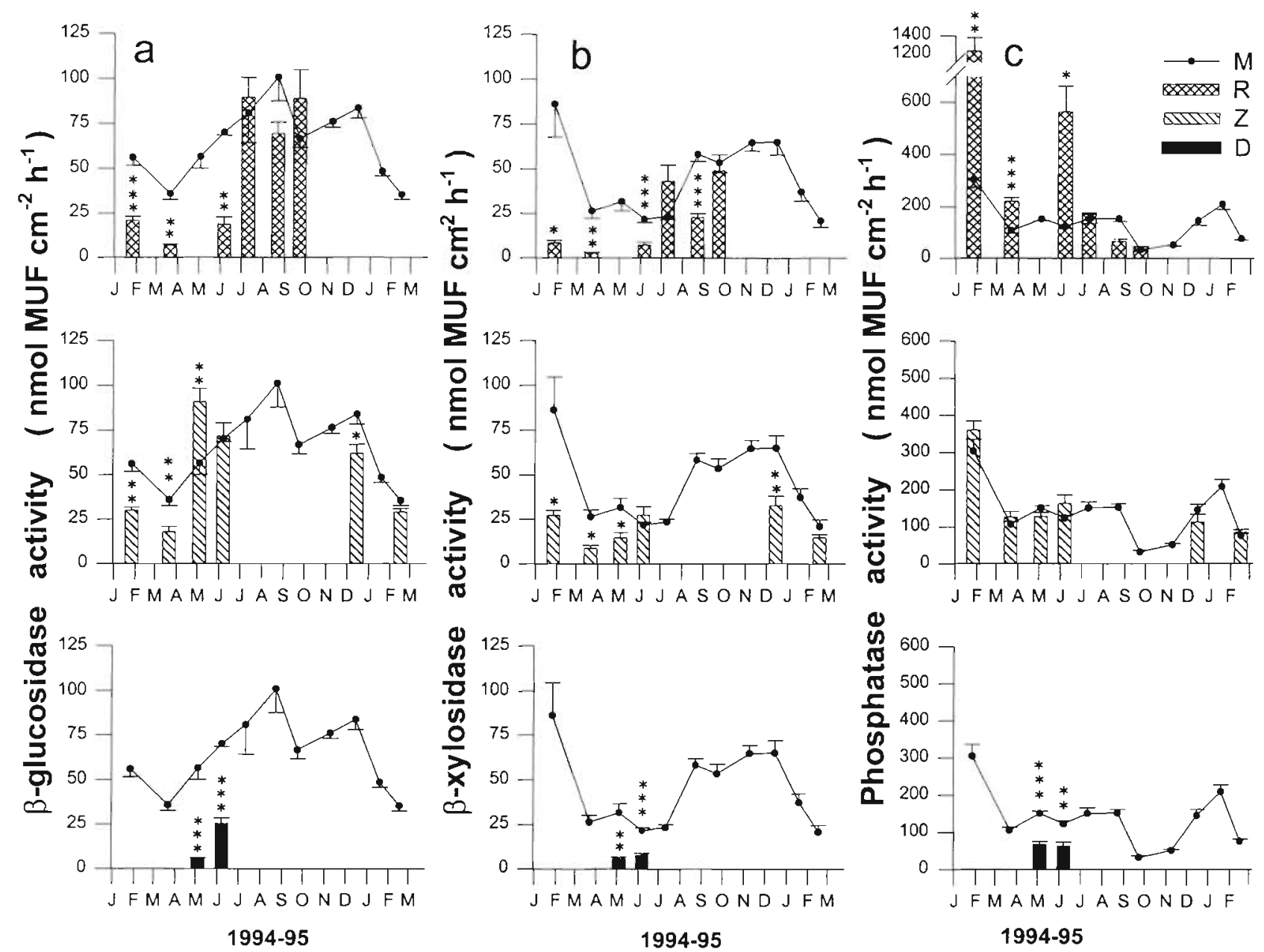

Fig. 3. Temporal variation of ectoenzymatic (a) $\beta$-glucosidase, (b) $\beta$-xylosidase, and (c) phosphatase activities in the different algal patches. M: mixed community; R: Rivularia community; Z: Zygnema-Spirogyra community; D: diatom bloom. Error bars represent standard errors of the mean, $n=5$. Significant differences between the $R, Z$ or $D$ community and the $M$ community on a given sampling date are indicated: $" \mathrm{p}<0.05,{ }^{*} \mathrm{p}<0.01,{ }^{\cdots}{ }^{*} \mathrm{p}<0.001(t$-test $)$

during winter and spring (Fig. 3b). In the Rivularia community, $\beta$-xylosidase was positively correlated to $\beta$-glucosidase $(r=0.96, p=0.002, n=6)$. $\beta$-Xylosidase activities in the diatom bloom were also lower (Fig. 3b). Concerning annual averages, $\beta$-xylosidase activity was significantly higher in the mixed community than in the other patches (Fig. 2).

The $\beta$-xylosidase : $\beta$-glucosidase ratio was around 0.5 except for the mixed community in winter 1994 (Table 3). Few variations in this ratio were detected in the Rivularia community over the study period. The Zygnema-Spirogyra community and the mixed community had higher seasonal fluctuations (Table 3 ).

Phosphatase activity in the mixed community had spring and summer values of between 100 and $150 \mathrm{nmol} \mathrm{cm}^{-2} \mathrm{~h}^{-1}$ (Fig. 3c). The highest activities were measured in winter (1994 and 1995), and the lowest in autumn 1994. Phosphatase activity in the Rivularia community was extremely high in January and June 1994, whilst in the Zygnema-Spirogyra community, values for this ectoen-

Table 3. $\beta$-Xylosidase: $\beta$-glucosidase ratio in the different algal patches. Values are seasonal means and standard error of the annual mean. M: mixed community; R: Rivularia community; Z: Zygnema-Spirogyra community; d: diatom bloom

\begin{tabular}{|lccccccc|}
\hline $\begin{array}{l}\text { Algal } \\
\text { patch }\end{array}$ & $\begin{array}{c}\text { Winter } \\
1994\end{array}$ & $\begin{array}{c}\text { Spring } \\
1994\end{array}$ & $\begin{array}{c}\text { Summer } \\
1994\end{array}$ & $\begin{array}{c}\text { Autumn } \\
1994\end{array}$ & $\begin{array}{c}\text { Winter } \\
1995\end{array}$ & Mean \pm SE & $\mathrm{n}$ \\
\hline $\mathrm{M}$ & 1.53 & 0.53 & 0.43 & 0.81 & 0.68 & $0.71 \pm 0.10$ & 11 \\
$\mathrm{R}$ & 0.40 & 0.39 & 0.40 & 0.55 & - & $0.42 \pm 0.03$ & 6 \\
$\mathrm{Z}$ & 0.90 & 0.34 & - & 0.53 & 0.50 & $0.49 \pm 0.10$ & 6 \\
$\mathrm{D}$ & - & 0.63 & - & - & - & $0.63 \pm 0.33$ & 2 \\
\hline
\end{tabular}



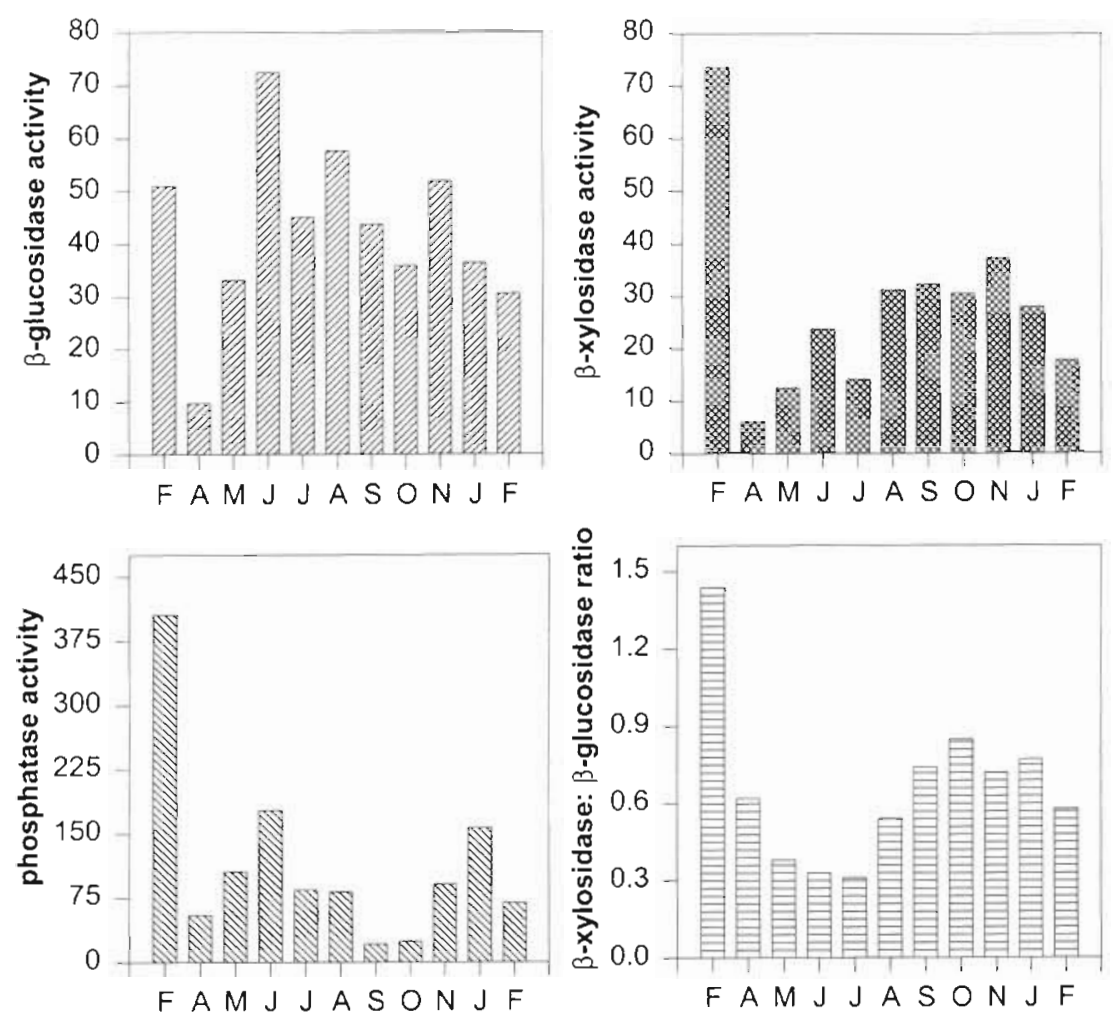

Fig. 4. Total ectoenzymatic activities $(\beta-$ glucosidase, $\beta$-xylosidase, phosphatase, in nmol MUF $\mathrm{cm}^{-2} \mathrm{~h}^{-1}$ ) in the streambed, and $\beta$-xylosidase: $\beta$-glucosidase ratio in La Solana. Values are the result of the potential ectoenzymatic activities for each patch referred to their respective surface area of streambed covered, later converted to the sum of all the different patches. The $\beta$-xylosidase: $\beta$-glucosidase ratio was calculated from the respective total activities

zyme were not significantly different than for the mixed community (Fig. 3c). Lowest phosphatase activity was found in the diatom bloom. Comparing the annual averages between the patches, phosphatase activity was significantly higher in the Rivularia community than in the other communities (Fig, 2).

\section{DISCUSSION}

Ectoenzymatic and respiratory activities measured in La Solana stromatolitic algal patches were much higher than in epilithic stream biofilms studied elsewhere (Marxsen \& Witzel 1990, Blenkinsopp et al. 1991. Sinsabaugh et al. 1991, Jones \& Lock 1993, Chappell \& Goulder 1994). However, values were not higher than in biofilms growing on wood surfaces (Sinsabaugh et al. 1991). The specific conditions of La Solana stream (calcareous watershed, low nutrient content, subject to the Mediterranean climate) led to the formation of this unusual streambed with a developed stromatolitic cyanobacterial crust. The high enzymatic and respiratory activities observed in La Solana may be related to the accumulation of organic matter within this thick stromatolite, as indicated by the high organic carbon and nitrogen content.

There is a general pattern of optimization in organic matter use that arises from the total ectoenzymatic ac- tivities in the streambed. When the potential ectoenzymatic activities for each patch are referred to their respective surface area of streambed covered, and converted to the sum of all the different patches, a meaningful picture is obtained (Fig. 4). The variation of the 3 ectoenzymatic activities in the streambed context shows, (1) the existence of a seasonal pattern and a rather extended plateau of maximum values throughout the hydrologic period and (2) the occurrence of an upper threshold of potential activities (that is seldom surpassed; a maximum in February is common for the 3 enzymes). In other words, the potential use of different organic matter sources is associated to a maximum but is however smoothed of extreme pulses of activity (either lower or higher), from a whole-stream perspective. This modulation is obvious when the total activity values (Fig. 4) are compared with those of the respective patches (Fig. 3).

The different patterns of variation among the enzymes (Fig. 4) might be an expression of their respective abilities to use specific high-molecular-weight compounds (Chróst 1990), as well as of the availability of substrates. The phosphatase degrades phosphomonoesters (Jansson et al. 1988); the $\beta$-glucosidase cleaves cellobiose molecules and is involved in the degradation of cellulose (Deshpande \& Eriksson 1988); and the $\beta$-xylosidase degrades xylobiose molecules (Lachke 1988) and is involved in the degradation of hemicellulose. 
The highest glucosidase and xylosidase potential activities and organic matter content were characteristic of the mixed community (Fig. 2). This community is permanent over the entire study period and occupied 60 to $80 \%$ of the streambed surface area. Therefore the potentially high capacity for the cleavage of polysaccharide molecules in this patch is extremely relevant for the organic matter use at the stream ecosystem level. The few algae and cyanobacteria constituting the overstorey of this patch indicate that the understorey of this stromatolitic crust is highly active. The activity in the permanent crust (understorey), along with the organic matter accumulated within it, is the basis for its key role as transformer of organic matter in the stream. This community may mainly use the organic matter accumulated in the stromatolite, such as extracellular polysaccharides and cyanobacterial sheaths (Lange 1976, Decho 1990). Glycolate excreted by the cyanobacteria (Bateston \& Ward 1988, Fründ \& Cohen 1992) may be the major source of organic carbon in microbial mats, together with organic compounds from fermentation (Stal 1995). The lower importance of autotrophy in the overstorey of this patch and the accumulation of allochthonous organic matter such as leaf fall and decaying plant material could enhance $\beta$-xylosidase activity (Jones \& Lock 1993), especially in autumn and winter (Table 3).

In the diatom bloom, algal excretion might regulate the lowest ectoenzymatic activities (Fig. 2). The monomeric compounds released by the diatoms, easily assimilable by bacteria, can repress extracellular enzymatic activities (Chróst 1990). The diatom bloom showed high chlorophyll a content with the lowest OD430/OD665 ratio (Fig. 2), suggesting its potential for high photosynthetic activity (Gotschalk \& Alldredge 1989) that would lead to important algal excretion. The accumulation of mucilage, mainly from the diatom stalks (Hoagland et al. 1993), and abundant algal excretion are revealed by the high organic carbon content (Fig. 2). However, the availability of DOC within the mucilaginous material (Decho \& Herndl 1995) might be responsible for the high respiratory activity found in this patch (Norrman et al. 1995). The enzymatic activities were not very variable throughout the duration of the diatom bloom, except for $\beta$-glucosidase which increased from May to June, coinciding with the aging of the mucilage (Herndl 1992, Middelboe et al. 1995) (Fig. 3a). This increase in $\beta$-glucosidase activity could be related to the greater proportion of substrate available for this enzyme after other enzymes (such as endoglycosidases) had degraded the mucilage to lower-molecular-weight molecules (Decho \& Herndl 1995). Although the high respiratory activity in this algal patch expressed high organic matter use, the patch made the lowest contribution towards the capacity to degrade high-molecular-weight molecules of the stromatolite. However, the development of the diatom bloom during spring leads to an accumulation of detritic material during the drought period, which might be used by the stromatolite as an organic matter source.

The Zygnema-Spirogyra community showed a shift in the $\beta$-xylosidase: $\beta$-glucosidase ratio between winter 1994 and spring 1994 (Table 3). The lower ratio in spring suggests the utilization of polysaccharides coming from algal release which mainly enhance $\beta$ glucosidase activity (Jones \& Lock 1993). The high biomass and photosynthetic activity in spring is characteristic of La Solana, especially for the Zygnematales community (Guasch \& Sabater 1994, 1995). It is likely that autotrophic activity does affect the organic matter source, leading to an increase in $\beta$-glucosidase activity. However, a short-term study would be required to prove such autotrophic-heterotrophic relationships. The increase in the $\beta$-xylosidase: $\beta$-glucosidase ratio in winter and autumn indicates that heterotrophs also cleave xylobiose molecules usually found in decaying plant material.

The Rivularia community was more constant in the use of a given organic matter source. Low variations in the $\beta$-xylosidase: $\beta$-glucosidase ratio were observed over the study period in this patch (Table 3 ). The high phosphatase and respiratory activities and OD430/ OD665 ratio (high carotenoid content) characterize this community. The extremely high phosphatase activity (Fig. 2) confers a resistance capacity during oligotrophic conditions; organic phosphorus sources are used to obtain inorganic phosphorus when this is scarce in stream water (Jansson et al. 1988, Boavida 1991, Whitton 1991). The highest phosphatase activity was measured in winter 1994, coinciding with minimum values of SRP in stream water. The genus Rivularia has a special ability to hydrolyse organic phosphates (Livingstone \& Whitton 1984). This gives this patch a competitive advantage over the other patches living in the phosphorus-limited La Solana (Guasch et al. 1995).

The $\beta$-xylosidase: $\beta$-glucosidase ratio (Fig. 4), calculated for the total activities in the streambed covered, indicates the progressive change in the source of organic matter used, from that of algal releases (low values of the ratio; spring-summer) to that of decaying plant material (higher values of the ratio; autumn-winter). This evolution stresses the adaptive response of the stromatolitic crust to the most available source of organic matter in the stream. Highest values in February indicate the absolute predominance in the use of allochthonous material as the organic matter source by the heterotrophs in that period. 
The different regulation of the ectoenzymatic activities in each patch and the thickness of this stromatolitic biofilm may underlie both the biofilm's ability to live in an oligotrophic stream and its capacity to resist the drastic changes in temperature, discharge and light of this Mediterranean stream. Drought caused a drastic decrease in bacterial density, photosynthetic activity and respiratory activity in the mixed community, but these activities recovered in 2 to $3 \mathrm{~h}$ (Romaní \& Sabater 1997). The appearance of the different algal patches during the year acts as an additional mechanism to exploit all energy inputs by using the adaptive capacity of each algal species. As has been observed in marine intertidal mats (Paerl et al. 1993), this behaviour optimizes carbon utilization in the system and is a good strategy for life under oligotrophic conditions.

Acknowledgements. This study was supported by the CICYT (project no. AMB93-0403) of the Spanish Science Ministry. We thank the 'Serveis Cientifics i Tècnics de la Universitat de Barcelona' for its technical assistance. Three anonymous referees provided very useful comments to the manuscript. A.M.R received an FPI grant from the Spanish Science Ministry.

\section{LITERATURE CITED}

Abdelahad N, Bazzichelli G (1989) Structure and composition of living stromatolitic mats from the terrestrial environment (Locality: Grotta dell'Inferniglio, Latium, Italy). Crypt Bot $1: 219-225$

Bateston MM, Ward DM (1988) Photoexcretion and fate of glycolate in a hot spring cyanobacterial mat. Appl Environ Microbiol 54:1738-1743

Blenkinsopp SA, Gabbott PA, Freeman C, Lock MA (1991) Seasonal trends in river biofilm storage products and electron transport system activity. Freshwater Biol 26:21-34

Blenkinsopp SA, Lock MA (1990) The measurement of electron transport system activity in river biofilms. Water Res $24: 441-445$

Boavida MJ (1991) Search for phosphomonoesters in Lake Maggiore (N. Italy) during summer. Mem Ist Ital Idrobiol 49:19-27

Canfield DE, Des Marais DJ (1993) Biogeochemical cycles of carbon, sulfur, and free oxygen in a microbial mat. Geochim Cosmochim Acta 57:3971-3984

Chafetz HS, Buczynski C (1992) Bacterially induced lithification of microbial mats. Palaios 7:277-293

Chappell KR, Goulder R (1994) Seasonal variation of extracellular enzyme activity in three diverse headstreams. Arch Hydrobiol 130:195-214

Chróst RJ (1990) Microbial ectoenzymes in aquatic environments. In: Overbeck J, Chróst RJ (eds) Aquatic microbial ecology: biochemical and molecular approaches. Springer-Verlag, New York, p 47-78

Chróst RJ (1991) Ectoenzymes in aquatic environments Microbial strategy for substrate supply. Verh Int Verein Limnol 24:2597-2600

Cohen Y, Rosenberg E (1989) Microbial mats: physiological ecology of benthic microbial communities. Am Soc Microbiol, Washington, DC

Decho AW (1990) Microbial exopolymer secretions in ocean environments: their role(s) in food webs and marine processes. Oceanogr Mar Biol Annu Rev 28:73-153
Decho AW, Herndl J (1995) Microbial activities and the transformation of organic matter within mucilaginous material. Sci Tot Environ 165:33-42

Deshpande V, Eriksson KE (1988) 1,4-ß-Glucosidases of Sporotrichum pulverulentum. In: Wood WA, Kellog ST (eds) Methods in enzymology, Part A, Cellulose and hemicellulose. Academic Press, Inc, San Diego, p 415-424

Fründ C, Cohen Y (1992) Diurnal cycles of sulfate reduction under oxic conditions in cyanobacterial mats. Appl Environ Microbiol 58:70-77

Gordon ND, McMahon T, Finlayson BL (1993) Stream hydrology, an introduction for ecologists. John Wiley \& Sons, Chichester

Gotschalk CC, Alldredge AL (1989) Enhanced primary productivity and nutrient regeneration within aggregated marine diatoms. Mar Biol 103:119-129

Grasshoff K, Ehrhardt M, Kremling K (1983) Methods of seawater analysis. 2nd edn. Verlag Chemie, Weinheim

Guasch H, Martí E, Sabater S (1995) Nutrient enrichment effects on biofilm metabolism in a Mediterranean stream. Freshwater Biol 33:373-383

Guasch H, Sabater S (1994) Primary production of epilithic communities in undisturbed Mediterranean streams. Verh Int Verein Limnol 25:1761-1764

Guasch H, Sabater S (1995) Seasonal variations in photosynthesis-irradiance responses by biofilms in Mediterranean streams. J Phycol 31:727-735

Hawes I (1993) Photosynthesis in thick cyanobacterial films: a comparison of annual and perennial Antarctic mat communities. Hydrobiologia 252:203-209

Herndl GJ (1992) Marine snow in the Northern Adriatic Sea: possible causes and consequences for a shallow ecosystem. Mar Microb Food Webs 6:149-172

Hoagland KD, Rosowski JR, Gretz MR, Roemer SC (1993) Diatom extracellular polymeric substances: function, fine structure, chemistry, and physiology. J Phycol 29:537-566

Jansson M, Olsson H, Pettersson K (1988) Phosphatases; origin, characteristics and function in lakes. Hydrobiologia 170:157-175

Jeffrey SW, Humphrey GF (1975) New spectrophotometric equations for determining chlorophylls $a, b$, and $c$ in higher plants, algae and natural phytoplankton. Biochem Physiol Pflanzen 167:191-194

Jones SE, Lock MA (1993) Seasonal determinations of extracellular hydrolytic activities in heterotrophic and mixed heterotrophic/autotrophic biofilms from two contrasting rivers. Hydrobiologia 257:1-16

Lachke AH (1988) 1,4-ß-D-Xylan xylohydrolase of Sclerotium rolfsii. In: Wood WA, Kellog ST (eds) Methods in enzymology, Part A, Cellulose and hernicellulose. Academic Press, Inc, San Diego, p 679-684

Lange W (1976) Speculations on a possible essential function of the gelatmous sheath of blue-green algae. Can J Microbiol 22:1181-1185

Livingstone D, Whitton BA (1984) Water chemistry and phosphatase activity of the blue-green alga Rivularia in Upper Teesdale streams. J Ecol 72:405-421

Margalef R (1983) Limnología. Ediciones Omega SA, Barcelona

Martí E, Armengol J, Sabater F (1994) Day and night nutrient uptake differences in a calcareous stream. Verh Int Verein Limnol 25:1756-1760

Martí E, Sabater F (1996) High variability in temporal and spatial nutrient retention in Mediterranean streams. Ecology 77:854-869

Marxsen J, Witzel KP (1990) Measurement of exoenzymatic activity in streambed sediments using methylumbellif- 
eryl-substrates. Arch Hydrobiol Beih Ergebn Limnol 34: $21-28$

Middelboe M, Sondergaard M, Letarte Y, Borch NH (1995) Attached and free-living bacteria: production and polymer hydrolysis during a diatom bloom. Microb Ecol 29: $231-248$

Norrman B, Zweifel UL, Hopkinson CS, Fry B (1995) Production and utilization of dissolved organic carbon during an experimental diatom bloom. Limnol Oceanogr 40:898-907

Paerl HW, Bebout BM, Joye SB, Des Marais DJ (1993) Microscale characterization of dissolved organic matter production and uptake in marine microbial mat communities. Limnol Oceanogr 38:1150-1161

Pinckney J, Paerl HW, Fitzpatrick M (1995a) Impacts of seasonality and nutrients on microbial mat community structure and function. Mar Ecol Prog Ser 123:207-216

Pinckney J, Paerl HW, Reid RP, Bebout B (1995b) Ecophysiology of stromatolitic microbial mats, Stocking Island, Exuma Cays, Bahamas. Microb Ecol 29:19-37

Romaní AM, Sabater S (1997) Metabolism recovery of a stromatolitic biofilm after drought in a Mediterranean stream Arch Hydrobiol 140:261-271

Editorial responsibility: Karel Simek, České Budějovice, Czech Republic
Sabater S, Romaní AM (1996) Metabolic changes associated with biofilm formation in an undisturbed Mediterranean stream. Hydrobiologia 335:107-113

Sinsabaugh RL, Golladay SW, Linkins AE (1991) Comparison of epilithic and epixylic biofilm development in a boreal river. Freshwater Biol 25:179-187

Stal LJ (1995) Physiological ecology of cyanobacteria in microbial mats and other communities. New Phytol 131: $1-32$

Stal LJ, Gemerden HV, Krumbein WE (1985) Structure and development of a benthic marine microbial mat. FEMS Microbiol Ecol 31:111-125

Triska FJ, Kennedy VC, Avanzino RJ, Zellweger GW, Bencala KE (1989) Retention and transport of nutrients in a thirdorder stream: channel processes. Ecology 70:1877-1892

Whitton BA (1991) Use of phosphatase assays with algae to assess phosphorus status of aquatic environments. In: Jeffrey DW, Madden B (eds) Bioindicators and environmental management. Academic Press, London, p 295-310

Winsborough BM, Golubic S (1987) The role of diatoms in stromatolite growth: two examples from modern freshwater settings. J Phycol 23:195-201

Submitted: June 23, 1997; Accepted: May 29, 1998

Proofs received from author(s): October 30 